\title{
Pengaruh Pemberian Ekstrak Etanolik Akar Kelor (Moringa oleifera, Lam) Terhadap Kadar Asam Urat dan Infiltrasi Sel Radang Jaringan Ginjal Tikus Putih (Rattus norvegicus) Model Diet Tinggi Lemak dan Induksi Streptozotocin-Nicotinamide.
}

\author{
Ynes Aulia Eka Damayanti ${ }^{1}$, Riza Novierta Pesik ${ }^{2}$, Widardo ${ }^{3}$, Dyah Ratna Budiani ${ }^{2}$ \\ 1. Fakultas Kedokteran, Universitas Sebelas Maret \\ 2. Bagian Patologi Anatomi, Fakultas Kedokteran, Universitas Sebelas Maret \\ 3. Bagian Gizi, Fakultas Kedokteran, Universitas Sebelas Maret
}

Korespondensi : auliadama@gmail.com

\begin{abstract}
ABSTRAK
Latar Belakang. Insidensi obesitas yang tinggi akibat diet tinggi lemak serta keadaan hiperglikemia menyebabkan stress oksidatif yang berujung pada infiltrasi sel radang di ginjal dan hiperurisemia. Fitokimia akar kelor bersifat antioksidan dan antidiabetik pada jaringan hepar, pankreas dan ginjal. Penelitian ini bertujuan untuk mengetahui pengaruh pemberian ekstrak akar kelor terhadap kadar asam urat dan infiltrasi sel radang jaringan ginjal tikus putih model diet tinggi lemak dan induksi streptozotocin-nicotinamide.

Metode. Penelitian eksperimental laboratorik dengan pretest-postest control group design untuk kadar asam urat dan postest only control group design untuk infiltrasi sel radang jaringan ginjal. Tikus jantan galur Wistar 30 ekor dibagi random menjadi 5 kelompok. K(1) kontrol negatif diberi pakan standard, K(II) diinduksi pakan tinggi lemak dan streptozotocinnicotinamide, K(III), (IV) dan (V) setelah induksi diberi variasi dosis ekstrak akar kelor 150, 250 dan $350 \mathrm{mg} / \mathrm{kgBB}$ selama 28 hari. Kadar asam urat diukur dengan Spektrofotometer kit DiaSys selama empat kali. Analisis hasil dengan one-way ANOVA dan post hoc Tukey HSD test serta repeated ANOVA dilanjutkan pairwise comparison Bonferroni. Persentase infiltrasi sel radang jaringan ginjal dianalisis dengan Kruskal-wallis dan post hoc Man whitney test. Analisis hubungan keduanya menggunakan Spearman.

Hasil: Terdapat perbedaan yang bermakna antara semua waktu pengukuran kadar asam urat ( $\mathrm{p}<0.05$, kecuali kelompok K3 antara hari ke-25 dan hari ke-57). Terdapat perbedaan signifikan kadar asam urat setelah pemberian ekstrak akar kelor antar kelompok. Terdapat perbedaan signifikan setelah diberikan ekstrak akar kelor pada persentase infiltrasi sel radang jaringan ginjal glomerulus antara $\mathrm{K}$ (I) dengan $\mathrm{K}$ (II), $\mathrm{K}$ (II) dengan $\mathrm{K}(\mathrm{V})$; dan antara $\mathrm{K}$ (II) dan $\mathrm{K}(\mathrm{V})$ pada jaringan ginjal tubulus. Persentase infiltrasi sel radang jaringan ginjal dan kadar asam urat setelah pemberian ekstrak akar kelor menunjukan hubungan yang bermakna dan berkorelasi positif kuat.

Simpulan: Ekstrak akar kelor dengan dosis 150, 250 dan 350mg/kgBB menurunkan kadar asam urat darah, dan dosis $350 \mathrm{mg} / \mathrm{kgBB}$ mampu menurunkan infiltrasi sel radang jaringan ginjal.
\end{abstract}

Kata Kunci: Ekstrak akar kelor; asam urat; infiltrasi sel radang; pakan tinggi lemak; Streptozotocin-Nicotinamide 
Damayanti et.al., Pengaruh Pemberian Ekstrak Etanolik Akar Kelor (Moringa oleifera, Lam) Terhadap Kadar Asam Urat dan Infiltrasi Sel Radang Jaringan Ginjal Tikus Putih (Rattus norvegicus) Model Diet Tinggi Lemak dan Induksi Streptozotocin-Nicotinamide.

\begin{abstract}
Background: The high incidence of obesity due to a high-fat diet and hyperglycemia causes oxidative stress which can lead to infiltration of inflammatory cells in the kidneys and hyperuricemia. Phytochemicals of Moringa root are antioxidant and antidiabetic in liver, pancreas and kidney tissue. This study aims to determine the effect of Moringa root extracts on uric acid levels and inflammatory cell infiltration of white rat kidney tissue in high-fat diet models and induction of streptozotocin-nicotinamide.

Methods: Laboratory experimental research with pretest-posttest kontrol group design for uric acid levels and posttest only kontrol group design for infiltration of inflammatory cells of kidney tissue. Samples of 30 Wistar strain male rats were randomly divided into 5 groups. $K(1)$ negatie kontrol was given standard feed, K(II) was induced by high-fat feed and streptozotocin-nicotinamide, K(III), (IV) and (V) after induction was given various dosage variations of Moringa root extract $150 \mathrm{mg} / \mathrm{kgBW}, 250 \mathrm{mg} / \mathrm{kg} \mathrm{kgBB}$ and $350 \mathrm{mg} / \mathrm{kgBB}$ for 28 days. Uric acid levels were measured with a DiaSys kit spectrophotometer four times. The results were analyzed by one-way ANOVA test and post hoc Tukey HSD test and repeated ANOVA test followed by pairwise comparison Bonferroni test. The percentage of inflammatory cells infiltration of kidney tissue was analyzed by the Kruskal-wallis test and the post hoc Man Whitney test. The relationship between the two was tested using the Spearman test

Results: There was a significant difference between all time measurements of uric acid levels ( $p<0.05$, except for the $K 3$ group between the 25th day and 57th day). There was a significant difference in uric acid levels after administration of Moringa root extract between groups. There was a significant difference after Moringa root extract was given in the percentage of inflammatory cells infiltration of glomerular kidney tissue between $K(I)$ with $K(I I), K(I I)$ with $K(V)$; and between $K(I I)$ and $K(V)$ in tubular kidney tissue. The percentage of inflammatory cells infiltration of kidney tissue and uric acid levels after administration of Moringa root extract showed a significant relationship and a strong positif correlation.

Conclusion: Moringa root extract with a dose of $150 \mathrm{mg} / \mathrm{kgBW}, 250 \mathrm{mg} / \mathrm{kgBW}$ and 350 $\mathrm{mg} / \mathrm{kgBW}$ significantly reduced uric acid levels, and with a dose of $350 \mathrm{mg} / \mathrm{kgBW}$ significantly reduced infiltration of inflammatory cells of kidney tissue
\end{abstract}

Keywords: Moringa root extract; uric acid; infiltration of inflammation cells; high-fat feed; Streptozotocin-Nicotinamide

\section{PENDAHULUAN}

Perubahan pola makan diet tinggi kalori dan penurunan aktivitas fisik menjadi faktor resiko penyakit kronis seperti obesitas, diabetes tipe 2 dan kardiometabolik. ${ }^{1} \quad$ Hasil studi epidemiologis di kota China, Kanada dan USA menunjukkan bahwa diet tinggi lemak menyebabkan insidensi obesitas meningkat, akibat peningkatan penyimpanan lemak di jaringan adiposa, hepar, dan serum. ${ }^{2-3}$ Hasil penelitian pada tikus Rattus norvegcius model diet tinggi lemak menunjukan peningkatan jumlah sel-sel inflamasi di ginjal secara histologi. ${ }^{4}$ Sel-sel inflamasi mensekresikan sitokin pro-inflamasi, fibrogenik, kemotraktan, dan molekul adesi yang dapat menarik sel darah putih (neutrofil, monosit, dan limfosit) yang berada di sirkulasi ke dalam jaringan ginjal. $^{5}$

Telah banyak hasil studi mengenai percobaan tikus dengan induksi streptozotocinnicotinamide menghasilkan model diabetes melitus tipe 2. ${ }^{6}$ Keadaan hiperglikemik mengakibatkan akumulasi advanced glycosylation end-products (AGEs), merupakan oksidan kuat yang mendorong kerusakan jaringan oleh radikal bebas 
Damayanti et.al., Pengaruh Pemberian Ekstrak Etanolik Akar Kelor (Moringa oleifera, Lam) Terhadap Kadar Asam Urat dan Infiltrasi Sel Radang Jaringan Ginjal Tikus Putih (Rattus norvegicus) Model Diet Tinggi Lemak dan Induksi Streptozotocin-Nicotinamide.

oksigen. ${ }^{7}$ Keadaan hiperglikemik kronis dan persisten dapat menurunkan aktifitas sistem antioksidan serta mendorong produksi radikal bebas yang dapat berujung pada kondisi stres oksidatif. ${ }^{8}$

Komposisi lipid ginjal mengandung polyunsaturated fatty acid (PUFA) rantai panjang yang tinggi, sehingga ginjal merupakan organ yang sangat rentan terhadap ROS. ${ }^{7}$ Peningkatan stress oksidatif intrarenal berhubungan dengan infiltrasi sel-sel imun, dan kedua proses ini bersifat umpan balik positif. ROS mengaktivasi sintesis sitokin dan kemokin proinflamasi, yang menyebabkan infiltrasi sel-sel imun di ginjal. Sel-sel imun seperti makrofag, monosit, dan limfosit $\mathrm{T}$ terbukti berfungsi sebagai pemicu produksi ROS. ${ }^{9}$ Terganggunya fungsi ginjal dapat menganggu fungsi organ tersebut dalam mengeliminasi produk akhir metabolisme tubuh seperti asam urat, yang berimplikasi pada keadaan hiperurisemia. ${ }^{10}$

Kelor (Moringa oleifera) merupakan tanaman yang tumbuh di negara beriklim tropis dan subtropis. Ekstrak aqueous kelor memiliki efek antioksidan dan antidiabetik pada jaringan hepar, pankreas dan ginjal. ${ }^{11}$ Kandungan antioksidan yang terdapat dalam kelor adalah saponin, alkaloid, fitosterol, tannin, fenolik, dan flavonoid. ${ }^{12}$ Senyawa fenolik dapat menghambat perioksidasi lipid dan ROS. ${ }^{13}$

Namun demikian, pengaruh pemberian ekstrak etanolik akar kelor terhadap kadar asam urat dan infiltrasi sel radang jaringan ginjal belum banyak dilaporkan. Oleh karena itu, penelitian ini dilakukan untuk mengetahui efek ekstrak etanol akar kelor (Moringa oleifera, Lam.) terhadap kadar asam urat dan infiltrasi sel radang jaringan ginjal tikus wistar (Rattus norvegcius) model diet tinggi lemak dan induksi streptozotocin-nicotinamide.

\section{SUBJEK DAN METODE}

\section{Sampel Penelitian}

Sampel penelitian menggunakan Tikus Putih (Rattus norvegicus) jantan galur Wistar umur 2-3 bulan dengan berat badan 150 - 200 gram, dibagi menjadi lima kelompok :

Kelompok I : Kontrol negatif

Kelompok II : Kontrol positif dengan pakan tinggi lemak (kuning telur bebek 1 $\mathrm{ml} / 100$ gramBB, lemak sapi $1 \mathrm{ml} / 100$ gram BB, minyak teroksidasi $1 \mathrm{ml} / 100$ gramBB) dan injeksi Nicotinamide (NA) $110 \mathrm{mg} / \mathrm{kgBB}$ serta Streptozotocin (STZ) $45 \mathrm{mg} / \mathrm{kgBB}$

Kelompok III : Pakan tinggi lemak, induksi STZ-NA, dan ekstrak akar kelor $150 \mathrm{mg} / \mathrm{BBkg}$

Kelompok IV : Pakan tinggi lemak, induksi STZ-NA, dan ekstrak akar kelor 250mg/BBkg

Kelompok V : Pakan tinggi lemak, induksi STZ-NA, dan ekstrak akar kelor $350 \mathrm{mg} / \mathrm{BBkg}$

\section{Pembuatan Ekstrak Akar Kelor}

Ekstraksi akar kelor menggunakan metode maserasi dengan pelarut etanol $70 \%$.

\section{Pengukuran Kadar Asam Urat}

Darah vena retroorbitalis diukur menggunakan kit DiaSys spektofotometer. Pengukuran dilakukan 4 kali : awal, sesudah pemberian pakan tinggi lemak, sesudah pemberian pakan tinggi lemak serta induksi STZ-Na, dan sesudah pemberian ekstrak akar kelor. 
Damayanti et.al., Pengaruh Pemberian Ekstrak Etanolik Akar Kelor (Moringa oleifera, Lam) Terhadap Kadar Asam Urat dan Infiltrasi Sel Radang Jaringan Ginjal Tikus Putih (Rattus norvegicus) Model Diet Tinggi Lemak dan Induksi Streptozotocin-Nicotinamide.

\section{Penghitungan Persentase Infiltrasi Sel \\ Radang Jaringan Ginjal}

Persentase infiltrasi sel radang di sediaan mikroskopis jaringan ginjal pengecatan Hematoksilin-Eosin (H\&E stain) dihitung dari rerata sembilan lapang pandang (tubular dan glomerulus) menggunakan pembesaran 400x.

Analisis Data

Kadar asam urat dianalisis dengan uji repeated ANOVA dan posthoc

Bonferroni. Persentase infiltasi sel radang jaringan ginjal dianalisis menggunakan Kruskal-Wallis dan post hoc Mann Whitney. Korelasi antar keduanya dianalisis menggunakan uji Spearman.

\section{HASIL}

\section{Kadar Asam Urat}

Tabel 2. Rerata kadar asam urat awal, sesudah pemberian pakan tinggi lemak, sesudah pemberian pakan tinggi lemak tinggi dan induksi stz-na, serta sesudah pemberian ekstrak akar kelor

\begin{tabular}{ccccc}
\hline $\begin{array}{c}\text { Kelo } \\
\text { mpok }\end{array}$ & $\begin{array}{c}\text { Rerata } \pm \text { Standard } \\
\text { Deviasi Awal } \\
(\mathrm{mg} / \mathrm{dL})\end{array}$ & $\begin{array}{c}\text { Rerata } \pm \text { Standard } \\
\text { Deviasi Sesudah } \\
\text { Pakan Tinggi } \\
\text { Lemak }(\mathrm{mg} / \mathrm{dL})\end{array}$ & $\begin{array}{c}\text { Rerata } \pm \text { Standard } \\
\text { Deviasi Sesudah Pakan } \\
\text { Tinggi Lemak dan } \\
\text { Induksi STZ-Na } \\
(\mathrm{mg} / \mathrm{dL})\end{array}$ & $\begin{array}{c}\text { Rerata } \pm \text { Standard } \\
\text { Deviasi setelah } \\
\text { Pemberian ekstrak } \\
\text { akar kelor }(\mathrm{mg} / \mathrm{dL})\end{array}$ \\
\hline I & $1.517 \pm 0.082^{a}$ & $1.635 \pm 0.059^{a}$ & $1.718 \pm 0.032^{a}$ & $1.787 \pm 0.090^{b}$ \\
II & $1.178 \pm 0.048^{c}$ & $5.547 \pm 0.047^{d}$ & $6.953 \pm 0.045^{e}$ & $7.615 \pm 0.254^{f}$ \\
III & $1.702 \pm 0.044^{g}$ & $6.123 \pm 0.051^{h}$ & $7.462 \pm 0.052^{i}$ & $5.852 \pm 0.307^{j}$ \\
IV & $1.613 \pm 0.071^{k}$ & $6.082 \pm 0.043^{l}$ & $7.442 \pm 0.042^{m}$ & $3.773 \pm 0.221^{n}$ \\
V & $1.493 \pm 0.065^{o}$ & $5.973 \pm 0.055^{p}$ & $7.325 \pm 0.081^{q}$ & $2.217 \pm 0.179^{r}$ \\
\hline Ken
\end{tabular}

Keterangan : Angka yang diikuti oleh huruf yang berbeda pada baris yang sama menunjukkan perbedaan signifikan

\section{Gambaran Infiltrasi Sel Radang Jaringan Ginjal}

Hasil persentase infiltrasi sel radang jaringan ginjal untuk glomerulus dan tubulus KI (0\%), KII (1\%), glomerulus KIII (0\%) dan tubulus KIII (1\%), KIV (0\%), serta KV $(0 \%)$. Hasil uji Kruskal-wallis persentase infiltrasi sel radang jaringan ginjal glomerlus antar kelompok menujukkan nilai $\mathrm{p}=0,006$, sedangkan untuk tubulus menunjukkan nilai $\mathrm{p}=0.021$. Hasil post hoc test untuk glomerulus menunjukkan nilai $\mathrm{p}<0,05$ pada kelompok III dan II-V. Sedangkan untuk tubulus nilai $\mathrm{p}<0,05$ pada kelompok II-V. Gambaran histopatologi infiltrasi sel radang jaringan ginjal dapat dilihat pada gambar 1 .

\section{Hubungan Infiltrasi Sel Radang Jaringan Ginjal dengan Kadar Asam Urat}

Hasil uji Spearman antara persentase sel infiltrasi sel radang jaringan ginjal glomerulus dan kadar asam urat menunjukkan nilai $\mathrm{p}=0,001$ dan $\mathrm{r}=+0.619$. Sedangkan hasil uji antara persentase sel infiltrasi sel radang jaringan ginjal tubulus dan kadar asam urat didapatkan nilai $\mathrm{p}=0,002$ dan nilai $\mathrm{r}=+0.598$. 
Damayanti et.al., Pengaruh Pemberian Ekstrak Etanolik Akar Kelor (Moringa oleifera, Lam) Terhadap Kadar Asam Urat dan Infiltrasi Sel Radang Jaringan Ginjal Tikus Putih (Rattus norvegicus) Model Diet Tinggi Lemak dan Induksi Streptozotocin-Nicotinamide.

Pembesaran 100x

Kelompok I

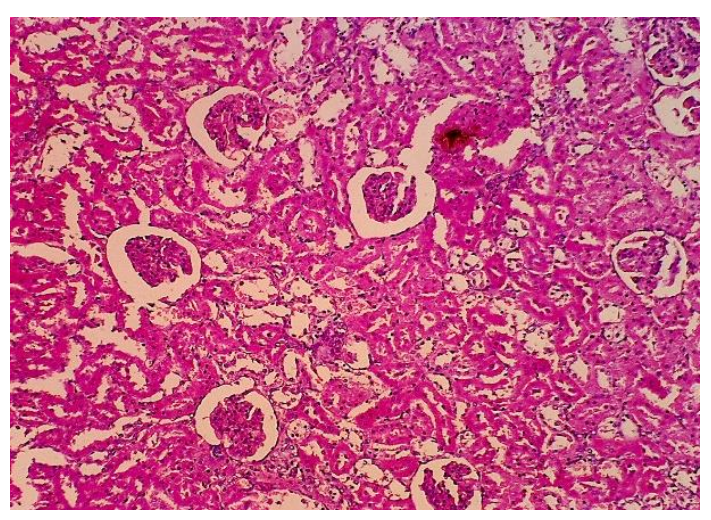

Kelompok II

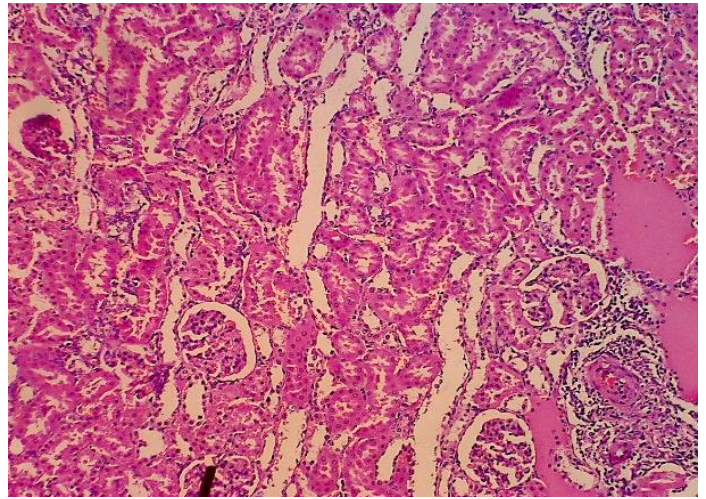

Kelompok III

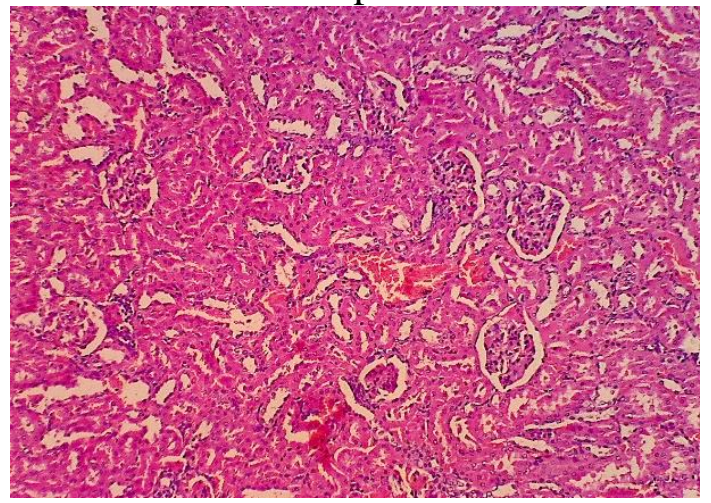

Pembesaran 400x

Kelompok I

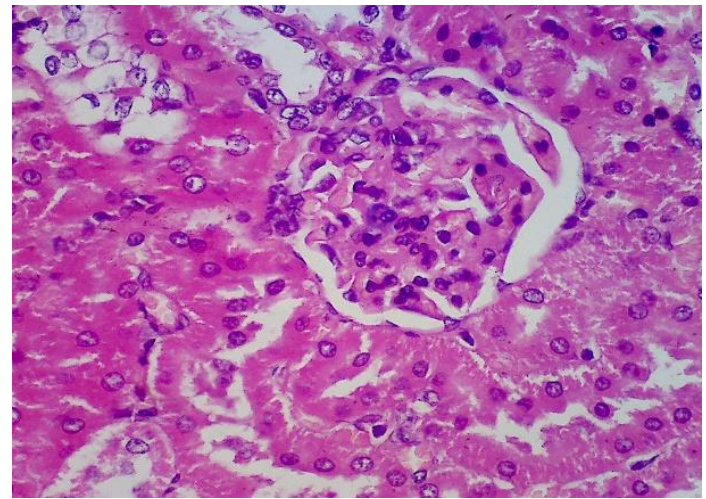

Kelompok II

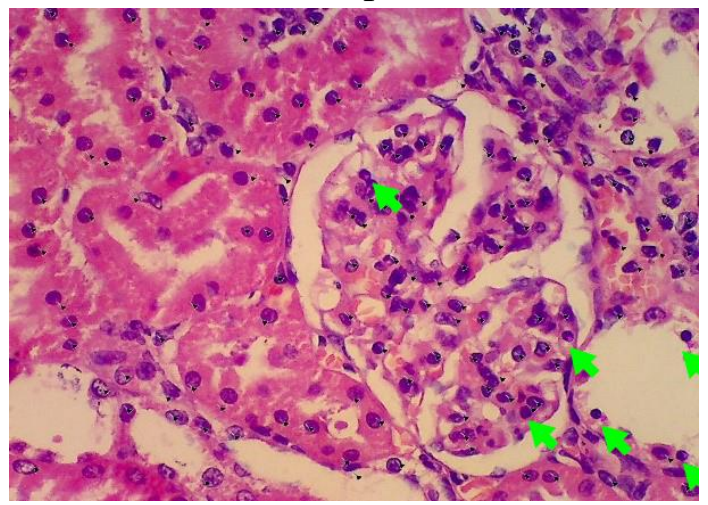

Kelompok III

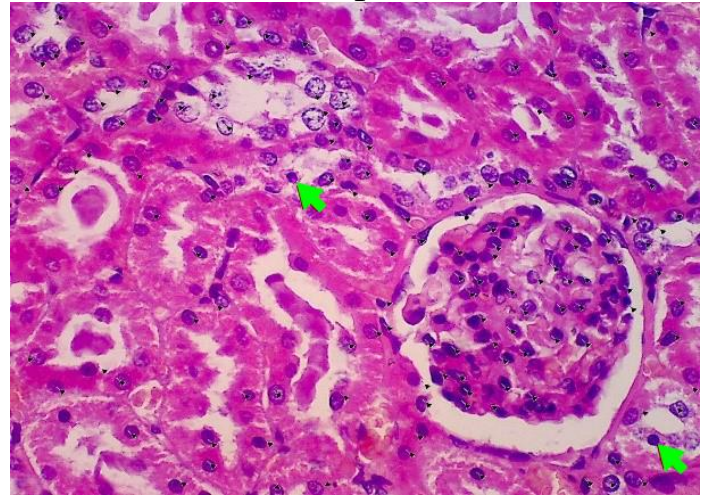


Damayanti et.al., Pengaruh Pemberian Ekstrak Etanolik Akar Kelor (Moringa oleifera, Lam) Terhadap Kadar Asam Urat dan Infiltrasi Sel Radang Jaringan Ginjal Tikus Putih (Rattus norvegicus) Model Diet Tinggi Lemak dan Induksi Streptozotocin-Nicotinamide.

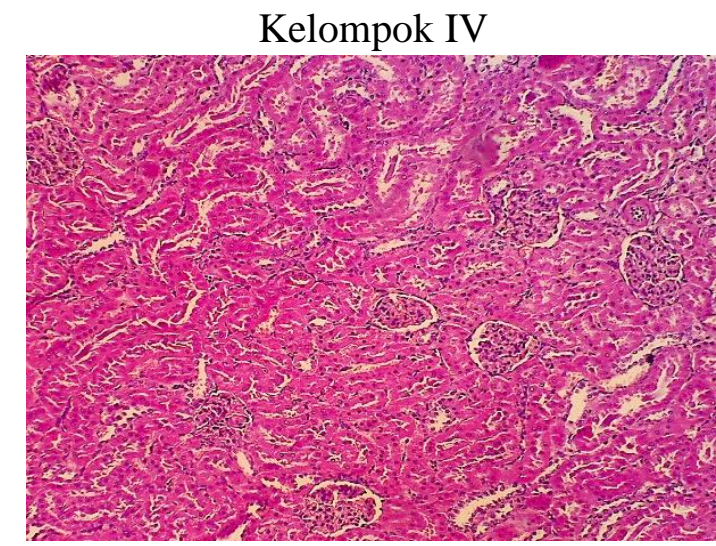

Kelompok V

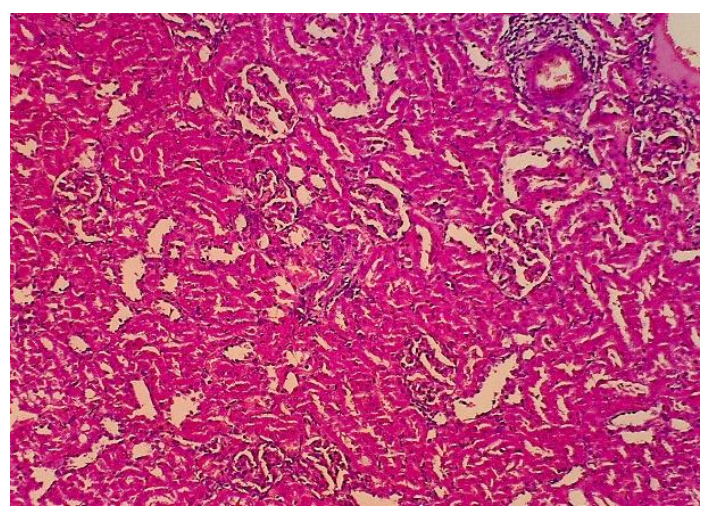

Kelompok IV

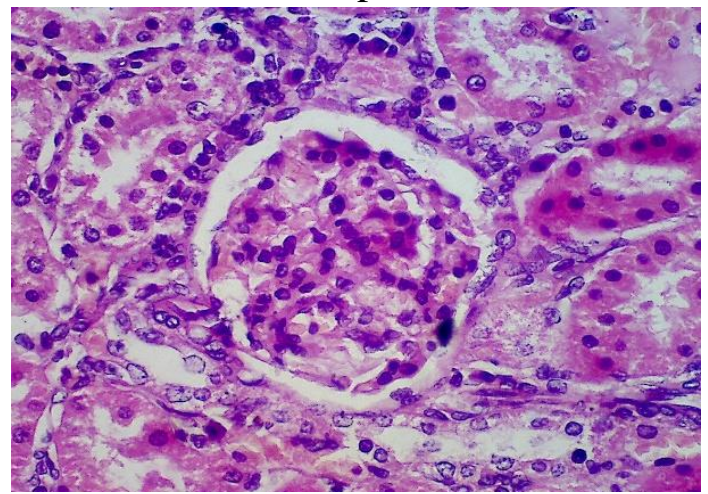

Kelompok V

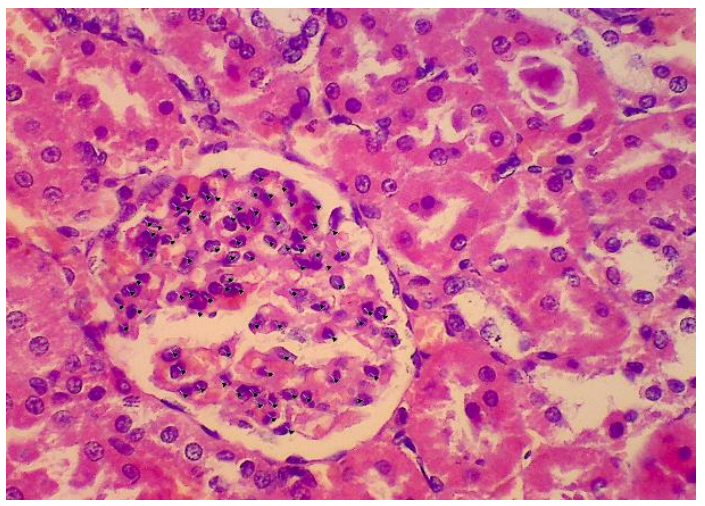

Gambar 1 Gambaran histopatologi infiltrasi sel radang jaringan ginjal (glomerulus dan tubulus) setelah pemberian diet tinggi lemak dan induksi STZ-NA, serta ekstrak akar kelor pada setiap kelompok dengan pewarnaan HE dan pembesaran 100 kali, 400 kali

Keterangan $\longrightarrow$ Sel radang limfosit

\section{PEMBAHASAN}

\section{Perbedaan Kadar Asam Urat Setelah Pemberian Diet Tinggi Lemak dan Induksi STZ-NA}

Pemberian diet tinggi lemak dan induksi STZ-NA selama 28 hari terbukti dapat meningkatkan kadar asam urat secara bermakna pada kelompok II, III, IV, dan V. Keadaan ini terjadi akibat akumulasi advanced glycosylation end-products (AGEs), yang mendorong kerusakan jaringan akibat radikal bebas oksigen. ${ }^{7}$ Peningkatan stress oksidatif intrarenal berhubungan dengan infiltrasi sel-sel imun, dan kedua proses ini bersifat umpan balik positif. ${ }^{9}$ Dua proses ini dapat menganggu fungsi ekskresi ginjal dalam mengeliminasi produk akhir metabolisme tubuh, seperti asam urat. $^{10}$

Keadaan hiperglikemia akibat disfungsi sel beta pankreas dan resistensi insulin menyebabkan hipertrofi nefron pada tahap awal disglikemia sebagai proses adaptif atau kompensasi untuk mencegah hilangnya glukosa. Hal ini ditandai dengan peningkatan reabsorbsi glukosa di tubulus proksimal dan peningkatan retensi urate. Terjadinya retensi urat disebabkan oleh transporter utama urat di sel tubulus proksimal (SCL2A9) yang juga berperan sebagai transport glukosa. ${ }^{14}$ Selain itu, peningkatan kadar trigliserida oleh penelitian Wardhani pada kontrol positif $137.02 \mathrm{mg} / \mathrm{dL}$ dibanding kontrol negatif 80.62 $\mathrm{mg} / \mathrm{dL}$, menjadi salah satu jalur terjadinya peningkatan kadar asam urat. ${ }^{15}$ Peningkatan 
Damayanti et.al., Pengaruh Pemberian Ekstrak Etanolik Akar Kelor (Moringa oleifera, Lam) Terhadap Kadar Asam Urat dan Infiltrasi Sel Radang Jaringan Ginjal Tikus Putih (Rattus norvegicus) Model Diet Tinggi Lemak dan Induksi Streptozotocin-Nicotinamide.

trigliserida menyebabkan peningkatan produksi asam lemak bebas (FFAs) yang mempercepat dekomposisi ATP, berujung pada peningkatan produksi asam urat. ${ }^{16}$

\section{Perbedaan Kadar Asam Urat Setelah Pemberian Diet Tinggi Lemak dan Induksi STZ-N, serta Ekstrak Akar Kelor}

Kadar asam urat menurun secara bermakna pada kelompok III (5.85 mg/dL), IV $(3.77 \mathrm{mg} / \mathrm{dL}), \mathrm{V}(2.22 \mathrm{mg} / \mathrm{dL})$. Penurunan kadar asam urat terjadi melalui beberapa mekanisme : Quercetin bersifat antioksidan kuat sebagai scavenger radikal bebas, mencegah oksidasi LDL, menghambat aktivitas xanthine oxidase; alkaloid bersifat mengurangi stress oksidatif dengan meningkatkan enzim antioksidan seperti SOD (Superoxide dismutase), CAT (Catalase), dan GPx (Glutathione peroxidase); saponin bersifat antikolesterolemia dengan membentuk kompleks kolesterol di GIT yang mencegah absorbsi oleh sel enterosit usus; vitamin $\mathrm{C}$ bersifat uricosuric yang membantu dalam ekskresi asam urat, karena penyebab utama hiperurisemia adalah penurunan eksresi asam urat (underexcretion 80-90\%), peningkatan metabolisme asam urat (overproduction 10$20 \%$ ), atau gabungan keduanya. ${ }^{17-20}$

\section{Perbedaan Persentase Infiltrasi Sel Radang Jaringan Ginjal Setelah Pemberian Diet Tinggi Lemak dan Induksi STZ-NA, serta Ekstrak Akar Kelor}

Peningkatan nilai persentase infiltrasi sel radang jaringan ginjal KI glomerulus $(0 \%)$ dan tubulus $(0 \%)$ dengan KII glomerulus $(1 \%)$ dan tubulus (1\%), terjadi karena akumulasi lipid di jaringan ginjal. Hal ini menyebabkan penurunan aktivitas AMPK (Adenosine monofosfat protein kinase), yang berfungsi dalam mengembalikan keseimbangan energi selular dengan menstimulasi jalur penghasil energi seperti oksidasi asam lemak dan menghambat sintesis asam lemak. Penelitian oleh Rachmah menyatakan bahwa terdapat peningkatan level MDA (Malondialdehyde) sebagai indikator jumlah radikal bebas pada kontrol positif $9.21 \mathrm{nmol} / \mathrm{ml}$ dibanding kontrol negatif $1.23 \mathrm{nmol} / \mathrm{ml}^{21}$ Peningkatan stress oksidatif berkorelasi dengan infiltrasi sel imun, dimana ROS mengaktivasi beberapa sitokin pro-inflamasi dan kemokin yang berujung pada infiltrasi sel imun pada jaringan ginjal. ${ }^{9}$

Perbedaan hasil yang bermakna pada persentase infiltrasi sel radang jaringan ginjal glomerulus antar kelompok terjadi di kelompok I-II dan II-V. Sedangkan, untuk jaringan ginjal tubulus pada kelompok II-V. Hal ini menunjukkan bahwa kadar optimum untuk menurunkan persentase sel radang jaringan ginjal adalah $350 \mathrm{mg} / \mathrm{kgBB} / \mathrm{hari}$.

Penurunan persentase infiltrasi sel radang jaringan ginjal terjadi melalui beberapa mekanisme : Quercetin sebagai golongan flavonoid bersifat antioksidan kuat, sebagai scavenger radikal bebas dan mencegah oksidasi LDL; alkaloid bersifat mengurangi level stress oksidatif dengan meningkatkan enzim antioksidan seperti SOD, CAT dan GPx; saponin bersifat antikolesterolemia dengan membentuk kompleks kolesterol di GIT sehingga mencegah absorbsi oleh sel enterosit usus; serta tannin, saponin, dan flavonoid bersifat anti-inflamasi. ${ }^{17-20}$

\section{Hubungan Perubahan Kadar Asam Urat dan Infiltrasi Sel Radang Jaringan Ginjal}

Kadar asam urat dan infiltrasi sel radang jaringan ginjal menunjukkan hasil yang berkorelasi positif. Hal ini disebabkan karena kadar asam urat yang tinggi dalam darah dapat meningkatkan reaksi oksidasi LDL serta menghasilkan peroksidasi lipid (MDA). Hal ini akan mengaktivasi NADPH oxidase yang berujung pada kondisi stres oksidatif. Peningkatan level oksidatif berkorelasi dengan infiltrasi sel imun, dimana ROS akan 
Damayanti et.al., Pengaruh Pemberian Ekstrak Etanolik Akar Kelor (Moringa oleifera, Lam) Terhadap Kadar Asam Urat dan Infiltrasi Sel Radang Jaringan Ginjal Tikus Putih (Rattus norvegicus) Model Diet Tinggi Lemak dan Induksi Streptozotocin-Nicotinamide.

mengaktivasi beberapa sitokin pro-inflamasi dan kemokin yang berujung pada infiltrasi sel imun pada jaringan ginjal. ${ }^{9}$ Dua proses ini dapat menganggu fungsi ekskresi ginjal dalam mengeliminasi produk akhir metabolisme tubuh seperti asam urat, karena $2 / 3$ total asam urat dieliminasi di ginjal dan sisanya di traktus gastrointestinal. $^{10,22}$

\section{SIMPULAN}

Ekstrak akar kelor (Moringa oleifera, Lam.) dosis $150 \mathrm{mg} / \mathrm{kgBB}, 250 \mathrm{mg} / \mathrm{kgBB}$ dan $350 \mathrm{mg} / \mathrm{kgBB}$ selama 28 hari dapat menurunkan kadar asam urat secara signifikan, dan dengan dosis $350 \mathrm{mg} / \mathrm{kgBB}$ dapat menurunkan persentase infiltrasi sel radang jaringan ginjal secara signifikan

\section{SARAN}

1. Dilakukan pemeriksaan immunohistokimia untuk mengetahui ekspresi sitokin-sitkokin proinflamasi

2. Dilakukan pemeriksaan rasio apolipoprotein-B terhadap apolipoprotein AI sebagai marker ideal dari terjadinya gangguan metabolisme lipid yang berhubungan dengan resistensi insulin dan sindrom metabolic.

\section{UCAPAN TERIMA KASIH}

Penulis mengucapkan terimakasih kepada kelompok penelitian kelor yang telah memberikan dukungan, bimbingan, kritik, dan saran yang sangat membantu selama penelitian hingga penulisan naskah publikasi ini

\section{DAFTAR PUSTAKA}

1. Jezewska-Zychowicz, M. et al. The Associations between Dietary Patterns and Sedentary Behaviors in Polish Adults. Nutrients. 2018:1-16

2. Hariri, N. \& Thibault, L. High-fat dietinduced obesity in animal models.
Nutrition Research Reviews. 2010: 270199.

3. Kanbay, M. et al. Uric acid in metabolic syndrome: from an innocent bystander to a central player. Eur J Intern Med. 2016:2.

4. Salim, H. M., Kurnia, L. F., Bintarti, T. W. \& Handayani. The effects of high-fat diet on histological changes of kidneys in rats. biomolecular and health science journal. 2018;01(02):111

5. Donate-Correa, J., Martin-Nunez, E., Muroz-de-Fuentes, M. \& al, e. inflammatory cytokines in diabetic nephropathy. journal of diabetes research.2015:2.

6. Ghasemi A, Khalifi S, Jedi S. Streptozotocin-nicotinamide-induced rat model of type 2 diabetes (Review). Acta Physiologica Hungarica.2014; 101(4):408-420

7. Ozbek, E. Induction of Oxidative Stress in Kidney. International Journal of Nephrology.2012:1-10.

8. Jaiswal, D. et al. Role of Moringa oleifera in regulation of diabetes-induced oxidative stress. Asian Pacific Journal of Tropical Medicine.2013:426-432.

9. Miguel, C. D. et al. Infiltrating $T$ lymphocytes in the kidney increase oxidative stress and participate in the development of hypertension and renal disease. Am $J$ Physiol Renal Physiol.2011;300:734-742

10. Sherwood, L. Human physiology : form cells to systems. 9 ed. United States: Cengage learning. 2016

11. Hawiest, T., Sriraksa, N., Wattanathron, J. \& Khongrum, J. The Antioxidative Effects of Moringa oleifera Lam. Leaves in the Higher Brain Regions of Diabetic Rats. $J$ Physiol Biomed Sci.2018;31(1):5-11.

12. MG, R., MN, S., K, E. \& B, S. Moringa oleifera Lam. A herbal medicine for hyperlipidemia : A preclinical report. asian pasific journal of tropical disease. 2012:790-795.

13. Owoade AO, Adetutu A, Aborisade AB. Protective effects of Moringa oleifera leaves against oxidative stress in diabetic rats. World Journal pf Pharmaceurical Sciences. 2017:64-71.

14. Andrade J.A.M. , Kang H.C., Greffin S., et al. Serum Uric Acid And Disorders Of Glucose Metabolism : The Role Of Glycosuria. Brazillian Journal of Medical 
Damayanti et.al., Pengaruh Pemberian Ekstrak Etanolik Akar Kelor (Moringa oleifera, Lam) Terhadap Kadar Asam Urat dan Infiltrasi Sel Radang Jaringan Ginjal Tikus Putih (Rattus norvegicus) Model Diet Tinggi Lemak dan Induksi Streptozotocin-Nicotinamide.

and Biological Research. 2014;47(10):917-923.

15. Wardhani T M. Pengaruh Ekstrak Akar Kelor (Moringa oleifera, Lam) Terhadap Kadar Trigliserida dan Histopatologi Steatosis Rattus norvegicus Model Sindroma Metabolik. Skripsi. Tidak Diterbitkan. Fakultas Kedokteran. Universitas Sebelas Maret : Surakarta. 2019

16. Hou Y-L, Yang X-1, Wang C-x, et al. Hypertryglyceridemia and hyperuricemia: a retrospective study of urban resident. Lipid in Health and Disease. 2019;18(81):1-5

17. Nuryanti A F. Pengaruh Pemberian The Daun Kelor Terhadap Kadar Asam Urat Pria Obesitas. Universitas Diponegoro. 2017

18. Atawodi, S. E. et al. Evaluation of the Polyphenol Content and Antioxidant Properties of Methanol Extracts of the Leaves, Stem, and Root Barks of Moringa oleifera Lam.. Journal Of Medicinal Food. 2010;13(3):714

19. Panda, S., Kar, A., Sharma, P. \& Sharma, A. Cardioprotective potential of $\mathrm{N}, \alpha-\mathrm{L}-$ rhamnophyranosyl vincosamide, an indole alkaloid, isolated from the leaves of moringa oleifera in isoproterenol induced cardiotoxic rats : In vivo and in vitro studies. bioorganic \& medicine chemistry letters. 2013:1-4.

20. Sharma, V. \& Paliwal, R. Isolation And Characterization Of Saponins From Moringa Oleifera (Moringaeceae) Pods. International Journal of Pharmacy and Pharmaceutical Sciences. 2013;5(1):179183

21. Rachmah A. Pengaruh Pemberian Ekstrak Etanolik Akar Kelor (Moringa oleifera, Lam) Terhadap Kadar MDA Plasma dan Ekspresi TNF-a Jaringan Otak: Tikus Putih (Rattus norvegicus) Model Sindroma Metabolik dengan Induksi Streptozotocin-Nicotinamide dan Diet Tinggi Lemak. Skripsi. Tidak Diterbitkan. Fakultas Kedokteran. Universitas Sebelas Maret : Surakarta. 2019

22. Riegersperger M, Covic A, Goldsmith D. Allupurinol,uric acid, and oxidative stress in cardiorenal disease. Int Urol Nephrol. 2011:441-449. 